\title{
Revize rozborů výzkumu efektu učitelova humorného působení na výsledky učení žáků a studentů ${ }^{1}$
}

\author{
Michaela Kubátová, Miroslav Klusák
}

\begin{abstract}
Abstrakt: Přehledová studie navazuje na tři relevantni přehledy výzkumù humoru v edukačnim prostredi. Soustredi se pouze na vyzkumy, v nichž byl zkoumán efekt humoru použivaného učiteli na výsledky učeni a "výsledky učeni" byly operacionalizované testy osvojených poznatkü. Otázkou je, jaké okolnosti ovlivňuji efekt humoru na učeni. Z rozboru 20 výzkumných studii vyplynulo devèt kategorii okolnosti, které problematizuji vliv humoru: trváni výuky; vztažnost humoru k látce; dávkováni humoru; techniky humoru; vnimáni humornosti studentem; individuálni charakteristiky studenta; charakter učiva; médium výuky; trénink učitele. Dle analyzovaných výzkumů pozitivni vliv na učeni podporuje: dlouhodobèjši trváni výuky; vztažnost humoru $k$ podstatným informacim; primérené a rovnomèrné dávkováni humoru; vkládáni humoru po vysvètleni nových poznatku a jejich opakováni po ilustrováni na humorném príkladu; aktivni práce s humorem ve výuce; trénink učitele; vnimáni humornosti studenty. Po dalšich výzkumech volá problematika individuálni charakteristiky studenta, charakteru učiva, a predevšim technik konstrukce humorné pointy.
\end{abstract}

Klíčová slova: humor učitele, vliv humoru na učeni, vztažnost humoru, techniky humoru

\section{ÚvOD}

V posledních desetiletích lze zaznamenat rostoucí množství výzev $\mathrm{k}$ systematickému používání humoru ve výuce. $\mathrm{V}$ roce 1988 Ziv zmiňuje existenci volitelného semináře Humor in teaching (Ziv, 1988). Na trhu se objevují učebnice používání humoru při výuce jako License to laugh: Humor in the classroom (Shade, 1996) nebo Magical management in the classroom: Using humor to speak their language (Gilliam, 2019). Výuku učitelům nabízí internetové platformy (např. Using humor in the classroom - educational psychology class $^{2}$ ). Otázkou je, nakolik mohou být návody zakotvené ve výzkumných zjišstěních.

\footnotetext{
1 Text je podpořen Grantovou agenturou Univerzity Karlovy (projekt č. 251-065).

2 Dostupné z https://study.com/academy/lesson/using-humor-in-the-classroom.html
} 
$\mathrm{Z}$ české odborné literatury je nutné zmínit monografii Humor ve škole od Kláry Šed'ové (2013), založenou na etnografickém výzkumu. A přehledovou studii Pedagogické efekty humoru ve výukové komunikaci od téže autorky, publikovanou v časopise Pedagogika v roce 2012. ${ }^{3}$

V publikacích čtenář najde teoretické části se zevrubnějšími výklady definice humoru, jeho typologií a funkcí ve školním prostředí. Pro tuto studii a základní orientaci v pojmech bude dostačující převzít definici humoru od Šed'ové: „Humor je specifický typ zážitku, který nastává v situaci paralelního výskytu dvou jevů, jež jsou normálně vnímány jako inkongruentní. Humor je založen na sociální interakci, přičemž si účastníci humorné situace vzájemně signalizují prítomnost hravého neseriózního percepčního rámce. Ambivalentní povaha humoru umožňuje vyjádřit potlačované a společensky nepřijatelné impulzy, př́ípadně emocionálně přepólovat význam vnímané situace." (Šed'ová, 2013, s. 20-21)

$\mathrm{V}$ této přehledové studii rozvíjíme podstatná zjištění přehledové studie Šed'ové a dvou relevantních přehledů, na něž autorka navazuje (Martin, 2007; Banas et al., 2011). Volbu daných přehledů jako komplexních a nejaktuálnějších můžeme podpořit na základě vlastní rešerše. Soustředíme se na dílčí téma efektu učitelova humorného působení na výsledky učení žáků a studentů, které je považované za prakticky nejdůležitější (Banas et al., 2011, s. 131).

V rámci Marešovy (2013) taxonomie a typologie se hlásíme $\mathrm{k}$ zaměření na přehled výsledků výzkumů (vs. metodologických prŕstupů, teorií či praktických aplikací) a $\mathrm{k}$ typu literárního prehledu. Tento literární přehled je specifický explicitní orientací na problematiku nastolenou předchozími přehledovými studiemi, jejichž rozbory máme za cíl rozvinout a prohloubit. A o jakou problematiku se jedná?

Ve studii Šed'ové (2012) je zajímavé závěrečné poselství. Autorka se neztotožňuje s popularizační literaturou, která učitelům pouze doporučuje hojné užívání humoru. Shrnuje, že zjištění experimentálních studií popírají „intuitivní představu vtipného učitele, který v uvolněné atmosfére baví své žáky spontánním žertováním“ (ibid., s. 439).

To neznamená, že by podle Šedové (2012) výzkumy nepřinášely svědectví o pozitivním vlivu humoru na učení. ${ }^{4}$ Otázkou je, zda lze výzkumně potvrdit, že použití humoru může mít pozitivní vliv na učení. Posláním těchto výzkumů je přinést důkazy o tom, že teze „Humor může mít pozitivní vliv na učení" nemá platnost pouze jako ideologické přání či dojem několika jednotlivých žáků, ale

\footnotetext{
3 Podle vyhledávače na webové stránce časopisu Pedagogika (https://pages.pedf.cuni.cz/pedagogika/?lang=cs) jde o jediný článek věnovaný problematice humoru v edukačním kontextu, který periodikum publikovalo od svého založení v roce 1951 do roku 2018. Za poslední dva roky se situace nezměnila.

4 Zde a dále v textu si dovolujeme termín „na učení " používat jako stručné vyjádření „na výsledky učení žáků a studentü“.
} 
jako zjištění statisticky významné tendence u početnějšśho výzkumného souboru. Cenné je, pokud tato zjištění přinášejí opakovaně a konzistentně. Jejich slabinou jsou př́pady, ve kterých se pozitivní vliv nepotvrdí. Důležité je, za jakých okolností dochází $\mathrm{k}$ pozitivnímu vlivu na učení. U výzkumů na toto téma přináší zjištěná absence pozitivního vlivu cennou informaci o okolnostech, které kladnému vlivu na učení nepřispívají, resp. mu mohou bránit. Pro přehledovou studii Šed’ové (ibid.) je hlavním tématem použití humoru a jeho pozitivní vliv na učení. Okolnosti způsobující tento pozitivní vliv jsou pro autorku pouze tématem doplňujícím. Obdobně jako v přehledech od Martina (2007) a Banase et al. (2011), na něž Šed'ová (2012) navazuje. ${ }^{5}$

Podíváme-li se na zmíněné tři přehledy z hlediska zájmu o okolnosti bránící/přispívající pozitivnímu vlivu humoru na učení, dojdeme k následujícím zjištěním.

\section{OKOLNOSTI BRÁNÍCí/PŘISPÍVAJÍCí POZITIVNÍMU VLIVU HUMORU NA UČENÍ PODLE PŘEHLEDOVÝCH STUDIÍ}

\section{Martin (2007)}

Autor se $\mathrm{v}$ knize The psychology of humor: An integrative approach věnuje přehledu výzkumů ve školství v subkapitole Humor v edukaci (Martin, 2007, s. 349-360). V textu navazuje na předchozí přehledy výzkumů $\mathrm{v}$ dané oblasti (Gruner, 1976; Bryant \& Zillmann, 1989; Teslow, 1995; Oppliger, 2003) a analyzuje původní výzkumné studie. ${ }^{6}$ Výzkumy člení dle otázek, na něž se snaží odpovědět: 1. Jak často a jakými způsoby učitelé typicky používají humor ve třídách? 2. Zlepšuje humor prostředí ve třídě a činí učení více radostné pro studenty? 3. Zlepšuje humor při výuce studentskou schopnost naučit se a zapamatovat si informace? 4. Pomáhá zahrnutí humoru do testů a zkoušek $s$ omezením úzkosti a zlepšením výkonu $\mathrm{v}$ testech? 5. Pomáhá humor v učebnicích jejich větší srozumitelnosti a zlepšuje studentskou schopnost naučit se látku? (Martin, 2007, s. 350)

Pro naše téma jsou důležité subkapitoly o výzkumech odpovídajících na otázku třetí a pátou a subkapitola doplňující, která prezentuje varování před problémy. $V$ těchto subkapitolách Martin analyzuje celkem 13 původních výzkumných studií (Bryant et al., 1981; Davies \& Apter, 1980; Derks, Gardner \& Agarwal, 1998; Gruner, 1967; Klein, Bryant \& Zillmann, 1982; Schmidt, 1994, 2002; Schmidt \& Williams, 2001; Wakshlag, Day \& Zillmann, 1981; Weaver, Zillmann \& Bryant, 1988; Zillmann et al., 1980, 1984; Ziv, 1988).

\footnotetext{
5 Šed'ová (2012) na s. 431 zmiňuje též metaanalýzu 20 výzkumných studií od Martina et al. z roku 2006. Tu se však nepodařilo vyhledat ani v jejím seznamu literatury, ani v seznamu literatury Martinovy monografie z roku 2007, ani na internetových seznamech jeho publikací.

${ }^{6}$ „Výzkumné studie“ používáme nejen v platnosti na časopisecké články, ale též na kapitoly v monografiích či sbornících a na závěrečné práce.
} 
V závěru Martin shrnuje, že přiměřené použití humoru ve výuce může vést $\mathrm{k}$ lepšímu učení a zapamatování informací, přestože jsou výsledky výzkumů „poněkud nekonzistentní“, „poněkud různorodé“ (2007, s. 359-360). Upozorňuje nejen na prŕípady, kdy se vliv humoru na učení nepodařilo zjistit, ale i na zjištění negativního vlivu: kdy humorné irelevantní se pamatuje lépe na úkor hůře zapamatovaných nehumorně prezentovaných klíčových pojmů.

$\mathrm{V}$ textu, který předchází závěru, se lze dočíst, že nižší frekvence humoru může vést $\mathrm{k}$ menší míře pozornosti (Martin, 2007, s. 354). Vysoká frekvence může vést $\mathrm{k}$ horšímu naučení a zapamatování látky (s. 356). Dále uvádí, že nedostatek vlivu by mohl vyplývat $\mathrm{z}$ krátkodobého trvání výuky (vyučovací hodina vs. pololetí; s. 355-356). Humor může být neefektivní, pokud se př́ímo nevztahuje $\mathbf{k}$ látce. Což připomíná efekt „na úkor“. Dále text informuje o tom, že vliv humoru na učení se nepodařilo zjistit ve výuce zprostředkované textem učebnice (s. 358). Také techniky konstrukce humorné pointy (jako nadsázka, zlehčení, zkreslení, kontradikce) mohou vést $\mathrm{k}$ nedorozumění a zmatení, zvláště v mladším školním věku (s. 359). Nedostatečný vliv humoru může být způsoben netrénováním učitelů $v$ jeho efektivním použití (s. 356).

\section{Banas et al. (2011)}

Autoři v článku $A$ review of humor in educational settings: Four decades of research vyčleňují kapitolu Vlivy výukového humoru (Banas et al., 2011, s. 129-135). V té se (vedle subkapitol Hodnocení vyučujícího, Prostředí třídy, Kredibilita a $\mathrm{Hu}-$ mor v edukačním testování) věnují přímo části Učení (s. 131-134). Při práci s původními výzkumnými studiemi nejdříve vyčleňují dvě studie týkající se vlivu humoru na pozornost (Wakshlag et al., 1981; Zillmann et al., 1980). Pro výzkumné studie týkající se osvojování a zapamatování informací zavádějí členění na ty, které informují o pozitivním vlivu humoru na učení, a ty, které informují o negativním vlivu či jeho absenci. Informacím o pozitivním vlivu se věnuje 13 výzkumných studií (Chapman \& Crompton, 1978; ${ }^{7}$ Davies \& Apter, 1980; Gorham, 1988; Hauck \& Thomas, 1972; Hays, 1970; Kaplan \& Pascoe, 1977; Kelley \& Gorham, 1988; Sanders \& Wiseman, 1990; Vance, 1987; Wakshlag et al., 1981; Wanzer \& Frymier, 1999; Zillmann et al., 1980; Ziv, 1988). Negativního vlivu se týká 10 výzkumných studií (Bryant et al., 1981; Gruner, 1967; Houser, Cowan \& West, 2007; Kennedy,

Příspěvek „Humorous presentations of material and presentations of material: A review of the humor and memory literature and two experimental studies" ve sborníku z konference M. M. Grunneberg, P. E. Morris \&R. N. Sykes (Eds.), Practical aspects of memory. London: Academic Press z roku 1978 se nepodařilo získat; nezahrnujeme ho do literatury na konci textu. 
1972; Kilpela, 1961; ${ }^{9}$ Markiewicz, 1972; $;^{10}$ Taylor, 1964; ${ }^{11}$ Weaver et al., 1988; Youngman, 1966; ${ }^{12}$ Zillmann et al., 1984). Jedna studie spadá do obou kategorií (Gorham \& Christophel, 1990).

Lze konstatovat, že Banas et al. (2011) pracují pouze s osmi ze 13 výzkumných studií analyzovaných Martinem (2007). Nejsou tedy důsledně kumulativní. Dále čtyřri výzkumné studie, které analyzují v rámci subkapitoly Učení (Gorham, 1988; Gorham \& Christophel, 1990; Kelley \& Gorham, 1988; Wanzer \& Frymier, 1999), Martin (2007) analyzuje v rámci subkapitoly pojednávající o vlivu humoru na prostředí třídy (Teacher's use of humor and the classroom environment), tedy o výzkumech odpovídajících na druhou z jeho pěti otázek (viz výše). Důvodem je zřejmě skutečnost, že ve výzkumech je pojem učení operacionalizovaný prostřednictvím (sebe)hodnotících dotazníků vyplňovaných studenty. Martin (ibid.) tzv. percipované učení (perceived learning) odlišuje od učení měřeného testy a začleňuje je pod hodnotící vztahy mezi žáky a učiteli, mohli bychom též ríct pod klima ve třídě.
Závěry subkapitoly Banas et al. (2011, s. 133) formulují v podobě výčtu důvodů, které mohou vést $\mathrm{k}$ rozdílným zjištěním o vlivu humoru na učení: A) Různá doba trvání výuky s humorem (pozitivní vliv se nedařilo zjistit při výuce kratšího trvání, v řádu minut). B) Vztah k látce (bez vztahu či se vztahem $\mathrm{k}$ probírané látce, resp. k jejím podstatným bodům; se závěrem o možném lepším zapamatování humorného irelevantního na úkor nehumorně prezentovaného relevantního). C) Různá média výuky (bezprostřední interakce učitele $s$ žáky, kreslený film, audiozáznam; bez komentáre o vztahu k vlivu humoru na učení). D) Vnímání zábavnosti učitelova humoru studenty (komentované politováním, že téměř žádný výzkum nekontroluje tuto proměnnou; což se netýká výzkumů, které pracují s dotazníky zadávanými studentům a studenty percipovaným učením).

$\mathrm{V}$ textu se můžeme dočíst, že vliv humoru se nepodařilo zjistit při jeho zavedení do výuky zprostředkované videonahrávkou. A že techniky humoru (jako nadsázka či ironie) mohou vést ke zmatení žáků mladšího školního věku (Banas et al., 2011, s. 132). Co se týče

\footnotetext{
8 Doktorská disertace $s$ názvem An experimental study of the effects of humorous message content upon ethos and persuasiveness, kterou se nepodařilo získat; nezahrnujeme ji do literatury na konci textu.

9 Magisterská práce s názvem An experimental study of the effect of humor on persuasion, kterou se nepodařilo získat; nezahrnujeme ji do literatury na konci textu.

${ }^{10}$ Doktorská disertace $s$ názvem The effects of humor on persuasion, kterou se nepodařilo získat; nezahrnujeme ji do literatury na konci textu.

${ }_{11}$ Banas et al. pracují s odkazem na text The effectiveness of humor in informative speeches (Central States Speech Journal, 5, 295-296), který se nepodařilo dohledat; nezahrnujeme jej do literatury na konci textu.

${ }_{12}$ Magisterská práce s názvem An experimental investigation of the effect of germane humor versus nongermane humor in an informative communication, kterou se nepodařilo získat; nezahrnujeme ji do literatury na konci textu.
} 
nedostatku tréninku učitelů v efektivním použití humoru, mohl by spočívat v absenci používání sekvence: výuka pojmu - jeho ilustrace vtipem - parafráze pojmu (ibid., s. 134). Lze říci, že Banas et al. (2011) zmiňují stejné kategorie okolností, jako zmiňoval Martin (2007). Navíc nabízí konkretizaci k problematice média výuky a nedostatku tréninku a zmiňují kategorii vnímání zábavnosti učitelova humoru žáky či studenty.

\section{Šed'ová (2012)}

Autorka $\mathrm{v}$ přehledové studii zaměřené na výzkumy vlivu humoru na učení ${ }^{13}$ explicitně navazuje na Martina (2007) a Banase et al. (2011). Sama, obdobně jako Martin (2007), rozlišuje výzkumné studie podle toho, zda byly výzkumy založené na dotaznících pro studenty, nebo na experimentech s využitím testů vědomostí. Do první skupiny o dotaznících patří čtyři výzkumné studie (Gorham \& Christophel, 1990; Torok, McMorris \& Lin, 2004; Wanzer \& Frymier, 1999; Wanzer, Frymier \& Irwin, 2010). Do druhé skupiny patří sedm výzkumných studií (Bingham \& Hernandez, 2009; Carlson, 2011; Kaplan \& Pascoe, 1977; Matarazzo, Durik \& Delaney, 2010; Schmidt, 1994; Ziv, 1976; Ziv, 1988). $\mathrm{Z}$ celkem 11 analyzovaných studií je pèt známých od Banase et al. (2011) či Martina (2007) či od obou autorů.

V závěru autorka shrnuje, že výzkumy založené na dotaznících pro studenty dokládají pozitivní vztah mezi humorem a učením, tedy tím percipovaným studenty. Výzkumy využívající testy vědomostí potvrzují pozitivní vztah mezi humorem a učením pouze částečně. Autorka uvádí: „Aby byl humor efektivní, musí být navázaný na látku a vhodně dávkovaný“ (Šed'ová, 2012, s. 439). V textu, který předchází závěru, Šed’ová (2012) parafrázuje výčet důvodů rozdílných zjištění, který uvedli Banas et al. (2011). Při následné analýze vybraných studií se soustředí na výzkumy relevantní pro vztah k látce a zapamatování humorného na úkor nehumorného: „Nejdůležitější je patrně sdělení, že si studenti lépe pamatují humorné stimuly, avšak může se tak dít na úkor stimulů ostatních“ (Šed’ová, 2012, s. 438).

Vůči předchozím dvěma přehledům Šed'ová (2012) neprovádí pouze redukci kategorií okolností. Rejstř́ík kategorií také obohacuje analyzováním výzkumné studie, podle které by humor mohl působit rozdílně na situační zájem dle míry dlouhodobého individuálního zájmu studentů o předmět: při nízké míre situační zájem zvyšovat, při vysoké míre rušit a snižovat (ibid., s. 437-438).

\section{Závěry $\mathrm{z}$ rozboru přehledových studií}

Získaný přehled působí mozaikovitě a není jasné, jak spolu jednotlivé kategorie souvisí ani jak vysvětlují rozporu-

13 Studii jako kapitolu s názvem Vztah humoru a učení zařadila autorka do knihy Humor ve škole (Šed'ová, 2013). 
plná zjištění výzkumů z hledisek: zjištěný pozitivní vliv, bez vlivu, negativní vliv. Revize rozborů výzkumných studií z hlediska hlavního zájmu o okolnosti bránící/přispívající pozitivnímu vlivu humoru na učení by situaci mohla řešit. Dále, zvláště s ohledem na studii Šed'ové (2012), by bylo vhodné probrat všechny kategorie kumulativně. Nabízí se otázka, zda autoři daných přehledových textů $\mathrm{z}$ analyzovaných výzkumných studií vytěžili všechny kategorie okolností. Revize je př́ležitostí vtáhnout do hry výzkumné studie, které autoři předchozích přehledových studií nevyužili nebo které jim nebyly dostupné.

\section{METODA - VÝBĚR VÝZKUMNÝCH STUDIÍ K ANALÝZE}

V prvním kroku byl výchozím zdrojem soubor všech studií uváděných autory předchozích přehledových studií v subkapitolách prezentujících výsledky rozboru výzkumných studií. $\mathrm{Na}$ rozdíl od autorů jsme vybrali pouze výzkumné studie, které pojem učení operacionalizovaly testováním osvojené a zapamatované látky. Vyřadili jsme studie, které kritériu neodpovídají a do souboru se dostaly kvůli nedůslednosti autorů.

Ze souboru jsme vyřadili studii, která studenty sice testovala, avšak Torranceho verbálním testem kreativního myšlení (Ziv, 1976). Vyřadili jsme také studii, která se zabývala jen vlivem na volbu z nabídky tř́i edukačních televizních programů, tedy vlivem na situační zájem či pozornost (Wakshlag et al., 1981).
Vyřadili jsme také studie z výzkumů, které učení operacionalizovaly pouze prostřednictvím tzv. percipovaného učení: Gorham (1988); Gorham a Christophel (1990); Klein et al. (1982); Sanders a Wiseman (1990); Torok et al. (2004); Wanzer a Frymier (1999); Wanzer et al. (2010).

Dále jsme vyřadili studii, která sice testovala míru osvojení informací, ale bezprostřednost (immediacy) neoperacionalizovala humorem učitele, nýbrž jen tělesnou blízkostí a očním kontaktem (Kelley \& Gorham, 1988); studii informující o rozboru dotazníku na klima $\mathrm{v}$ komunikaci s učitelem ve třídě, ve kterém ani jedna ze 48 položek nezmiňuje humor učitele (Hays, 1970); a studii, ve které se nejednalo o humor učitele, nýbrž o humorné asociace žáků (Hauck \& Thomas, 1972).

Výběr 17 výzkumných studií $\mathrm{k}$ analýze jsme přebrali od autorů předchozích studií. Je pečlivý vůči výše uvedenému kritériu pro jejich zahrnutí. Na rozdíl od Banase et al. (2011) a Šed'ové (2012) a s ohledem na Martina (2007) je důsledně kumulativní.

Ve druhém kroku jsme rešerše předchozích autorů prověřili novou rešerší prostřednictvím vyhledávače Univerzity Karlovy UKAŽ, který slučuje nejvýznamnější elektronické databáze: např. Scopus, Web of Science, EBSCO eBooks, Academic Search Ultimate a další. Byla využita klíčová slova v anglickém jazyce: humour at school, humour in classroom, humor and learning, humor in teaching; i v jazyce českém: humor 
Tab. 1. Přehled výzkumných studií vybraných $\mathrm{k}$ analýze $(\mathrm{N}=20)$

\begin{tabular}{|l|c|c|}
\hline Autor & Rok & Zjišš̌ný vliv na učení \\
\hline Gruner & 1967 & $\mathrm{NE}$ \\
\hline Gruner & 1970 & $\mathrm{NE}$ \\
\hline Kaplan \& Pascoe & 1977 & $\mathrm{ANO}+/-$ \\
\hline Davies \& Apter & 1980 & $\mathrm{ANO}+$ \\
\hline Zillmann et al. & 1980 & $\mathrm{ANO}+$ \\
\hline Bryant et al. & 1981 & $\mathrm{NE}$ \\
\hline Zillmann et al. & 1984 & $\mathrm{ANO}-$ \\
\hline Vance & 1987 & $\mathrm{ANO}+$ \\
\hline Weaver, Zillmann \& Bryant & 1988 & $\mathrm{ANO}-$ \\
\hline Ziv & 1988 & $\mathrm{ANO}+$ \\
\hline Schmidt & 1994 & $\mathrm{ANO}+/-$ \\
\hline Derks, Gardner \& Agarwal & 1998 & $\mathrm{ANO}+$ \\
\hline Schmidt \& Williams & 2001 & $\mathrm{ANO}+$ \\
\hline Schmidt & 2002 & $\mathrm{ANO}+$ \\
\hline Rule \& Auge & 2005 & $\mathrm{ANO}+$ \\
\hline Houser, Cowan \& West & 2007 & $\mathrm{NE}$ \\
\hline Bingham \& Hernandez & 2009 & $\mathrm{ANO}+$ \\
\hline Matarazzo, Durik \& Delaney & 2010 & $\mathrm{NE}$ \\
\hline Carlson & 2011 & $\mathrm{ANO}+$ \\
\hline Bolkan, Griffin \& Goodboy & 2018 & $\mathrm{ANO}-$ \\
\hline
\end{tabular}

Pozn.: + = pozitivní vliv; $-=$ negativni vliv $;+/-=$ pozitivní i negativní vliv

ve škole, humor ve trídě, humor a učeni, humor ve výuce. Výstupem byly práce publikované v letech 1967-2018. Jednalo se o články z recenzovaných časopisů, monografie nebo jejich kapitoly, články ze sborníků i závěrečné práce.

Vyřadili jsme studie, kterým scházel vlastní empirický výzkum at už kvalitativního, kvantitativního, nebo smíšeného rázu. Dále jsme vyřadili studie, které nesplňovaly kritérium: výzkumná studie se zabývá vlivem humorného působení učitele na výsledky učení žáků a studen- tů a tento efekt ověřuje testováním osvojené a zapamatované látky.

Výběr studií nebyl omezen $\mathrm{z}$ hlediska původu autorů, charakteristik pokusných osob či konkrétní podoby metodologického postupu. Požadavkem bylo, aby zkoumané soubory osob a metodologické postupy byly $\mathrm{v}$ textech řádně popsané. V rozboru jsou zohledněny role charakteristik pokusných osob (např. věk), a pokud se to jevilo jako relevantní, i konkrétního metodologického postupu. 
$\mathrm{Na}$ základě rešerše soudíme, že soubor výzkumných studií používaných předchozími přehledovými studiemi je dobré rozširirit o tř̌i dalš̌i studie: Bolkan, Griffin a Goodboy (2018); Gruner (1970); Ruleová a Auge (2005).

Výsledný soubor studií $\mathbf{k}$ analýze prezentujeme $\mathrm{v}$ tabulce 1 , uspořádané podle data publikace. Ve všech 20 studiích byly použity kontrolní skupiny, ve kterých se nepracovalo s humorem. ANO+ či ANO- znamená, že pozitivní či negativní vliv humoru na výsledky v testech byl u experimentální skupiny statisticky významný ve srovnání se skupinou kontrolní.

VÝSLEDKY - OKOLNOSTI BRÁNÍCíl PŘISPÍVAJíCÍ POZITIVNÍMU VLIVU HUMORU NA UČENÍ

\section{Trvání výuky}

Martin (2007) a Banas et. al. (2011) píši o krátkodobém trvání výuky jako o okolnosti ovlivňující vliv humoru na učení. Nenabízí však nápovědu, proč by mělo bránit pozitivnímu vlivu. Tu nabízejí Bryant et al. (1981) ${ }^{14}$. Absenci vlivu vysvětlují tak, že nedošlo k záměrnému učení ze strany studentů (test nebyl ohlášený; bez studia textu s podtrháváním, opakovaným čtením atd.). ${ }^{15}$ Houserová et al. (2007) ${ }^{16}$ absenci vlivu vysvětlují tím, že při jednorázovém a krátkodobém sledování videopřednášky bylo kognitivní úsilí studentů vyčerpáno nejednoznačností vyplývající z méně přirozené komunikace. Studentům nezbývalo sil na přijetí pozitivního vlivu humoru či neverbální bezprostřednosti. ${ }^{17}$

U těchto autorů nejde o samotné trvání výuky, spíše o její jednorázovost. Navíc to, že by pozitivnímu vlivu bránilo krátkodobé trvání výuky či její jednorázovost, popírá výzkum Kaplana a Pascoea (1977), ${ }^{18}$ v němž studenti jednorázově sledovali 20 minut trvající

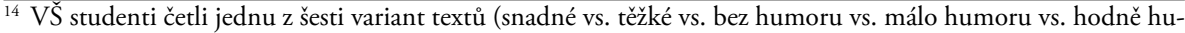
moru); humor zprostředkovaný kreslenými vtipy - ilustrujícími text; texty hodnotili pomocí dotazníku o devíti otázkách; následně podstoupili test o 12 otázkách na doplnění vět (polovina k humorně ilustrované látce).

${ }^{15}$ Autoři nepotvrdili pozitivní vliv jako statisticky významný, i když bezprostředně zjistili tendenci obdobnou jako Kaplan a Pascoe (1977). Pravděpodobně proto, že jejich tendence byla statisticky významná až při druhém testování po šesti týdnech. Bryant et al. (1981) testovali jen bezprostředně, i když výzkum dvojice Kaplan a Pascoe (1977) znali.

${ }^{16}$ VŠ studenti individuálně sledovali videozáznamy jedné ze čtyř variant přednášky na DVD (bez/s neverbální bezprostředností vs. bez/s humorem - via komické př́klady a vtipy) a hodnotili pomocí dotazníku; následoval test o pěti otázkách $\mathrm{k}$ hlavním pojmům.

${ }^{17}$ Spíše je pravděpodobné, že se autoři neseznámili s výzkumem dvojice Kaplan a Pascoe (1977) či Schmidta (1994) a nezavedli citlivost vůči vlivu „na úkor“ (viz níže kapitolu Vztažnost humoru k látce).

${ }^{18}$ VŠ studenti ve skupinách sledovali jednu ze čtyř variant videozáznamu přednášky o šesti hlavních pojmech (varianty: bez humoru, $s$ humorem nevztaženým $\mathrm{k}$ hlavním pojmům, vztaženým pouze ke třem hlavním pojmům a $\mathrm{k}$ šesti hlavním pojmům). Následoval test na šest hlavních pojmů a na pět pojmů vedlejších, prezentovaných vždy bez humoru. Při testování po přednášce byla statistická tendence jen naznačena; při testování po šesti týdnech se prosadila jako statisticky významná: studenti si pamatovali šest inkriminovaných pojmů $\mathrm{v}$ gradaci od „bez humoru“ $\mathrm{k}$,s humorem vztaženým ke všem šesti pojmům“.
} 
videonahrávku přednášky. Totéž popírá výzkum Schmidta (1994), ${ }^{19}$ v němž studenti četli 20 vět napsaných na samostatných stranách a stránky otáčeli na zvukový signál v intervalu 10 sekund. Je srozumitelné, že Šed'ová (2012) trvání výuky jako problematickou okolnost nevyčleňuje a ve vztahu $\mathrm{k}$ času píše o dávkování. K hlubšímu pochopení kategorie dávkování je vhodné obsáhnout kategorii vztažnosti humoru $\mathrm{k}$ látce.

\section{Vztažnost humoru k látce}

Martin (2007), Banas et al. (2011) i Šed’ová (2012) zmiňují, že humor má pozitivní vliv na učení, pokud je vztažen $\mathrm{k}$ informaci, kterou se mají studenti naučit. Humorný prvek by měl na učivo navazovat, doplňovat ho nebo ilustrovat či s ním alespoň tematicky souviset. Zároveň upozorňují na komplikaci spojenou s touto okolností. Objev komplikace zřejmě patří dvojici Kaplana a Pascoea (1977).

Když Gruner (1976) publikoval přehled výzkumů vlivu humoru na učení, pouze jeden výzkum ${ }^{20}$ potvrzoval jeho vliv; jednalo se o vliv pozitivní, jeho zjištění však označil za nevěrohodné. Mezi výzkumy byly i jeho vlastní (Gruner, $\left.1967,{ }^{21} 1970^{22}\right)$. Ačkoli vkládal vtipy odpovídající obsahu, $\mathrm{k}$ rozdílu v zapamatování obsahu nedošlo, i když ve druhém výzkumu přidáním humoru dosáhl vyššího hodnocení zajímavosti u varianty nezáživné obsahem a přednesem. Teprve Kaplan a Pascoe (1977) jako první použili experimentální design (viz výše). Zjistili, že šest pojmů prezentovaných $s$ humorem si studenti zapamatovali lépe na úkor pěti pojmů prezentovaných bez humoru. Pozitivní a negativní vliv se kompenzoval a výsledky za celý test se $u$ přednášek $s$ humorem a bez humoru nelišily, stejně jako $\mathrm{v}$ předchozích výzkumech.

Tendence $\mathrm{k}$ zapamatování humorně podaného učiva na úkor zapamatování učiva podaného nehumorně byla naznačena či potvrzena $v$ dalších výzkumech. Bryant et al. (1981) tendenci zaznamenali, nebyla však statisticky významná. Schmidt (1994) ji potvrdil pro pamět na věty a zároveň ukázal, že pokud byly všechny informace podány humorně, vliv humoru na učení byl nulový - studenti si toho zapamatovali stejně, jako když všechny informace byly podány bez humoru (viz výše). Později výsledky

\footnotetext{
19 V základní podobě experimentů VŠ studenti četli jednu ze tří variant 20 vět (polovina humorná, všechny humorné, žádná humorná); následně počítali 5 minut jednoduché aritmetické př́klady; následoval test paměti na věty. Lépe si pamatovali věty humorné ze smíšeného souboru; mezi pamětí na věty ze souborů všechny humorné vs. žádná humorná nebyl rozdíl.

${ }^{20}$ Odkazuje na magisterskou závěrečnou práci: Gibb, J. D. (1962). An experimental comparison of the humorous lecture and the nonhumorous lecture in informative speaking. M.A. Thesis, University of Utah.

${ }^{21}$ VŠ studenti poslouchali jednu z variant audionahrávky projevu (bez humoru vs. s humorem); následoval test na obsah projevu formou otázek s volbou odpovědi.

${ }^{22}$ VŠ studenti poslouchali jednu ze čtyř variant audionahrávky projevu (zajímavou vs. nezáživnou obsahem i přednesem vs. bez humoru vs. $s$ humorem); následoval test na obsah projevu formou otázek s nabídkou odpovědí.
} 
replikoval s kreslenými vtipy (Schmidt, $\left.2002^{23}\right)$. Tendenci potvrdili i Derks et al. (1998). Ti, inspirováni Freudovou teorií humoru, zavedli do Schmidtova (1994) designu další nezávislou proměnnou v podobě agresivní sexuality. Zjistili, že má mnohem větší pozitivní vliv na pamět než humor a že se může $s$ humorem spojit a jeho vliv posilovat - uvědomují si ale, že to $\mathrm{z}$ morálních důvodů nelze využít v běžné školní praxi.

Existují však studie, které potvrzují pozitivní vliv humoru, který nebyl vztažený $\mathrm{k}$ látce. Průkopnická byla studie Zillmanna et al. (1980), ${ }^{24}$ ve které autoři chtěli humorem vyvolat bdělost před prezentací nové, testované látky. Nava- zovala studie Vanceho (1987), ${ }^{25}$ kterému se podařilo prokázat pozitivní vliv doplňkového humoru (contiguous), nevztažený a předcházející nové látce. $\mathrm{Ne}-$ potvrdil se však předpokládaný rušivý vliv integrovaného humoru (integrated) vztaženého $\mathrm{k}$ nové látce a prezentovaného současně s ní. Negativní vliv integrovaného humoru byl zjištěn ve studii trojice Bolkan, Griffin a Goodboy (2018). ${ }^{26}$ A to dokonce $\mathrm{v}$ situaci, kdy humorné pŕíklady pojmů byly $\mathrm{v}$ písemném textu zařazeny v sekvenci: 1 . výklad nové látky, 2. ilustrace látky humorným př́ikladem, 3. parafrázování nové látky - požadované jako žádoucí načasování Zivem (1988; viz níže). $V$ daném případě si však sami

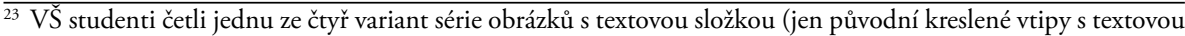
složkou vs. jen komentované obrázky bez inkongruence vs. jen komentované obrázky bizarní - s inkongruencí bez humorného řešení vs. série smíšená z předchozích tří druhů komentovaných obrázků); následoval test žádající popis obrázků a reprodukci textové složky.

${ }^{24}$ Děti ve věku 5;6-7;2 sledovaly ve dvojicích jednu z pěti variant série čtyř televizních vzdělávacích programů, které trvaly v průměru 3 minuty 33 sekund. Humor spočival v osmi 30 sekund trvajících komických skečích z loutkového seriálu The Muppets - bez jakéhokoli vztahu k obsahu vzdělávacích programů. Varianty: humor vkládán v rychlém tempu - jeden skeč uprostřed a jeden na konci každého vzdělávacího programu; humor vkládán $\mathrm{v}$ pomalém tempu - dva skeče na konci každého vzdělávacího programu; bez humoru - pauzy v rychlém tempu; bez humoru - pauzy v pomalém tempu; bez humoru - bez pauz. Následoval test formou rozhovoru - 10 otázek ke každému vzdělávacímu programu. Množství zapamatovaného z prvního programu se nelišilo. Ve třech variantách bez humoru množství zapamatované látky z 2.-4. programu pokleslo, a to bez rozdílů mezi variantami a programy. Ve variantách s humorem množství zapamatovaného postupně stoupalo; při humoru v pomalém tempu však až od 3. programu.

${ }_{25}$ Žáci 1. ročníku se účastnili jedné ze čtyř variant situací: 1. Ve skupině opakovaně poslouchali audionahrávku četby známého dětského př́iběhu; následně ihned poslouchali nahrávku verze se smích vyvolávajícími změnami obsahu (např. záměna druhů zvírátek v roli hrdinů); a následně ihned poslouchali př́běh o výletu do knihovny, kde hrdinové našli několik knížek o zvíratech. 2. Stejná posloupnost jako v první variantě, jen před poslech nahrávky humorné verze byla vložena týdenní přestávka. 3. Stejná posloupnost, bez humorné verze známého př́iběhu a se zavedením humorných prvků do nového příběhu pomocí devíti ilustrujících obrázků zvírat, z nichž čtyři byly neadekvátně zařazené. 4 . Stejná posloupnost bez humoru. Následoval test verbálně zadávanými otázkami.

${ }^{26}$ VŠ studenti četli jednu z variant textu (příklad pojmu s/bez použití humoru - humor via absurdní nadsázka); následně 10 minut řš̌ili matematické a logické úkoly; následovalo 10 minut na test o pěti otázkách s volbou odpovědí na zachování (retain) a převod (transfer) informace.
} 
autoři vysvětlují negativní vliv problematikou použité techniky humoru (absurdní nadsázka). Nezavedli ji ale jako kontrolovanou proměnnou, pouze o ní uvažovali.

Problematika vztažnosti $\mathrm{k}$ látce vstupuje do hry jiným způsobem, jedná-li se o využití humoru $\mathrm{k}$ mobilizaci obsahově nespecifické bdělosti nebo $\mathrm{k}$ obsahově specifické mobilizaci psychofyziologických mechanismů paměti (jejího posílení prožitou emocí) či vyšších úrovní myšlení (viz níže). V druhých dvou př́ipadech je třeba uvažovat jak o komplikaci zapamatování na úkor, tak o komplikaci použitými technikami humoru.

\section{Dávkování humoru}

O dávkování píše Šed’ová (2012); Martin (2007) konkrétně o frekvenci; Banas et al. (2011) kategorii mezi problematickými okolnostmi nezmiňují.

Kategorie má platnost vůči množství humoru. Klíčové jsou již výzkumy k problematice vztažnosti $\mathrm{k}$ látce. Zvláště když Schmidt (1994) ukázal, že pokud byly všechny informace podány humorně, vliv humoru na učení byl nulový. Bryant et al. (1981) uvádí mírnou tendenci ve směru čím více humoru, tím méně si studenti zapamatovali učivo nespjaté s humorem. Ziv $(1988)^{27}$ uvažoval, že by množství humoru nemuselo negativně působit jen na psycho- fyziologické úrovni, ale též na symbolické. Na základě výzkumů vnímání učitele studenty držel ve své studii maximální hranici vtipů na čtyřech za lekci. Důvodem bylo, aby učitel nebyl vnímán jako klaun. Z toho vyplývá, že pozitivnímu vlivu humoru na učení by mohlo bránit př́liš velké množství humoru.

S tím souvisí i frekvence užívání humoru při výuce. Zillmann et al. (1980) se touto otázkou zabývali (humor vkládaný v rychlém vs. pomalém tempu) při využívání humoru nevztaženého $\mathrm{k}$ látce $\mathrm{k}$ vyvolávání bdělosti u dětí $\mathrm{v}$ MŠ. V souhrnném množství zapamatované látky rozdíl nezjistili. Zjistili však rozdíl, který vyplýval z načasování - pokud při rychlém tempu začali humor vkládat dříve, projevil se pozitivní vliv na učení také dříve. Ziv (1988) použil nepravidelnou frekvenci, aby učitel v průběhu semestru působil přirozeně, nikoli mechanicky: v některých přednáškách zmínil až čtyři vtipné príklady, v některých žádný.

Pro Ziva (1988) bylo zřejmě nejdůležitější načasování. Všechny vyprávěné či kreslené vtipy byly vztaženy $\mathrm{k}$ učivu nejen obsahově, ale též $\mathrm{v}$ závazné posloupnosti $\mathrm{k}$ jeho výkladu. Učitel je využíval v sekvenci: 1 . výklad nové látky, 2. ilustrace látky humorným př́kladem, 3. parafrázování nové látky.

V návaznosti na Ziva (1988), přitom nezávisle na něm, postupovali Ruleová

\footnotetext{
${ }_{27}$ VŠ studenti se účastnili jedné varianty semestrálního kurzu (s humorem vs. bez humoru). Vyprávěné či kreslené vtipy byly zvoleny/zkonstruovány tak, aby ilustrovaly vybrané podstatné pojmy, které budou testované v závěrečném testu - 50 otázek s volbou odpovědi. Variantu bez humoru učil stejný učitel. Experiment proběhl $\mathrm{v}$ kurzu úvod do statistiky, následně znovu s jiným učitelem a jinými studenty v kurzu úvod do psychologie. V obou prrípadech byl statisticky významný pozitivní vliv humoru ověrený testem.
} 
a Auge (2005), ${ }^{28}$ když rozvinuli inspiraci teorie didaktického využití analogií a usilovali o mobilizaci vyšších úrovní myšlení (bigher level thinking skills). Spojením výuky látky $\mathrm{z}$ geologie $s$ výukou analýzy a tvorby humoru dali kategorii dávkování humoru nový význam. Obdobně tomu bylo ve výzkumu dvojice Bingham a Hernandez (2009), ${ }^{29}$ kteří zařazovali promítání videoklipů po výkladu nových pojmů, aby vyvolali zevrubnou diskusi $\mathrm{k}$ analýze humoru a teorii sociálního jevu, s níz si komik zahrává.

Dávkování humoru je otázkou optimalizace vůči povaze jeho využití ve výuce. Jde-li o využití humoru k mobilizaci obsahově nespecifické bdělosti, jsou požadavky na načasování vzhledem k výkladu a opakování nové látky odlišné než $\mathrm{v}$ př́padě jeho využití $\mathrm{k}$ obsahově specifické mobilizaci psychofyziologických mechanismů paměti (jejího posílení prožitou emocí) či vyšších úrovní myšlení. Frekvence může být pravidelná, množ- ství by nemělo převýšit kapacitu látky. Obdobně je tomu při využití k obsahově specifické mobilizaci psychofyziologických mechanismů paměti. Při využití k obsahově specifické mobilizaci vyšších úrovní myšlení by množství humoru a jeho frekvence neměly bránit jeho pozitivnímu vlivu na symbolické úrovni učitel by neměl být vnímán jako klaun.

\section{TeChNIKY HUMORU}

Martin (2007) uvádí, že techniky humoru jako nadsázka, zlehčení, zkreslení či kontradikce mohou vést $\mathrm{k}$ nedorozumění a zmatení studentů a žáků, zvláště v mladším školním věku. Obdobně se vyjadřují o nadsázce a ironii Banas et al. (2011). Šed'ová (2012) techniky humoru mezi problematickými okolnostmi nezmiňuje.

Problematice se věnovala studie Zillmanna et al. (1984). ${ }^{30}$ Zjistili, že nadsázka

\footnotetext{
${ }^{28}$ Žáci 6. ročníku se účastnili jedné z variant výuky o nerostech a horninách, trvající sedm vyučovacích hodin. Varianty: 1. s humorem o nerostech a bez humoru o horninách; 2 . bez humoru o nerostech a s humorem o horninách. Výuku prováděl stejný učitel; bez humoru: výklad, diskuse, práce s textem a pracovními listy; s humorem: výklad, diskuse, ilustrace kresleným vtipem, žáci analyzovali kreslené vtipy z hlediska látky a humoru, zdokonalovali kreslené vtipy v dimenzi zábavnosti a množství informace, za domácí úkol vytváreli vlastní kreslené vtipy k vyučované látce. Míra znalostí osvojených za celou výuku testovaná pretestem a posttestem. Statisticky významně více se žáci naučili v hodinách $s$ humorem.

${ }^{29} \mathrm{VŠ}$ studenti se účastnili jedné z variant kurzu úvodu do sociologie (s použitím a bez použití humorných videoklipů, které komici prezentují na internetu). Experimentální skupina dopadla lépe jak v průběžných testech, tak v závěrečné klasifikaci; ovlivněny nebyly seminární práce na obsahovou analýzu reklamy.

${ }^{30}$ Děti z MŠ, 1. a 4. ročníku ZŠ ve dvojici (stejného věku) sledovaly jednu ze čtyř verzí 16 minutového vzdělávacího televizního programu: 1. humor bez zkreslení (distortion-free) - dvě postavy zkoumají vlastnosti exotického ovoce (láhevník ostnitý, chlebovník obecný, karambola) s použitím formálně žertovného až šprýmovného jazyka a adekvátním zobrazením vlastností (např. ,štavnatost“ láhevníku vymačkáním skleničky štávy); 2. humor s kompatibilním zkreslením, nadsázka - via interakce herců s objektem, a to i s použitím filmových triků (nap̌̌. „štavnatost“ láhevníku ilustrovaná vymačkáním nekončícího proudu); 3. humor s nekompatibilním zkreslením, ironie (např. ,štavnatost“ láhevníku ilustrovaná vymačkáním jedné kapky); 4. humor s nekompatibilním zkreslením následovaným opravou - vysvětlení protikladu (láhevník byl nezralý, zralý by skleničku naplnil). Následně 8 minut program o zviŕatech; následně rozhovor o zábavnosti a test na tř́ídení ovoce z hlediska vyučovaných vlastností (Kolik štávy z láhevníku: kapka, lžíce, hrneček, hrnek, džbánek, kbelík?).
} 
a ironie vedly $\mathrm{k}$ vyšší zábavnosti a $\mathrm{k}$ významnému nadhodnocování či podhodnocování vyučované látky vůči kontrolní skupině. Opravovaná/vysvětlovaná ironie nevedla $\mathrm{k}$ vyšší zábavnosti, vedla však ke srovnatelnému podhodnocování jako ironie neopravená/nevysvětlená. $S$ rostoucím věkem aktérů se negativní vliv nesnížil. V navazující studii (Weaver et al., 1988) autoři použili obdobný po$\operatorname{stup}^{31}$ s dětmi 4. a 8. ročníku ZŠ a dospěli ke stejným výsledkům, a to i u žáků 8. ročníku. Bolkan et al. (2018) zjistili, že v případě absurdní nadsázky může mít humor negativní vliv i u VŠ studentů (viz výše).

Techniky humoru, resp. významotvorné, poetické figury, které jsou založené na zkreslení povahy absurdní nadsázkou či zlehčení ironickou kontradikcí, mohou tedy působit rušivě. Výzkumně neprozkoumaná zůstává otázka alternativ. Jak je tomu u ostatních poetických figur? Je bezpečné používat humor využívající např. metafory nebo metonymie - tropů komplementárních $\mathrm{k}$ ironii? Zajímavá je př́padně i otázka vztahu $\mathrm{k}$ povaze začlenění do výuky. Platil by rušivý vliv nadsázky/zlehčení a ironie i v situaci, kdy by žáci byli vedeni alespoň $\mathrm{k}$ analýze humorných př́íkladů vyučovaných pojmů jako u autorů Ruleová a Auge (2005)?

\section{Vnímání humornosti studentem}

$\mathrm{Z}$ trojice přehledových studií pouze Banas et al. (2011) zmiňují tuto kategorii, podle nich je tato proměnná ve studiích kontrolována nedostatečně, což je poněkud zarážející. Pokud by zkoumaní žáci a studenti nepovažovali prezentovaný humor za zábavný, nesmáli by se a k humoru by nedošlo. Následně jejich tvrzení působí nesrozumitelně, nebot́ ve všech studiích autoři zábavnost materiálu kontrolovali, at jeho hodnocením $\mathrm{v}$ předvýzkumech, či v průběhu výzkumu. Existují však studie, které poznatku o rozdílné míře kontroly smysl dávají - když míra žáky/studenty vnímané humornosti je měřená a používaná jako nezávislá proměnná.

Schmidt (1994) takto operacionalizoval rozdíl „s humorem / bez humoru“ v některých podobách výzkumů paměti na věty (viz výše). Míru vnímané humornosti použili Schmidt a Williams $(2001)^{32}$ jako nezávislou proměnnou v první fázi svých výzkumů. Zjistili, že pamět na komentované obrázky byla lepší u těch, které byly vnímány humorněji, a to i $\mathrm{v}$ př́padě obrázků $\mathrm{z}$ kategorie bizarních (s inkongruencí bez humorného řešení) či bez inkongruence. Ve druhé fázi výzkumů paměti na kreslené vtipy, umožňující prozkoumat efekt „na úkor“,

\footnotetext{
${ }^{31}$ Rozdíl byl v tom, že děti sledovaly program ve skupinách, a místo rozhovoru autoři použili dotazník.

${ }^{32} \mathrm{~V}$ základní podobě VŠ studenti četli jednu ze tř́ ekvivalentních variant série obrázků s textovou složkou (vždy smíšené z původních kreslených vtipů s textovou složkou, z komentovaných obrázků bez inkongruence a z komentovaných obrázků bizarních $-\mathrm{s}$ inkongruencí bez humorného řešení). Následně 5 minut řešili aritmetické úkoly; následně proběhl test na pamět žádající popis obrázků a reprodukci textové složky.
} 
Schmidt (2002) zjištění zopakoval. V navazujícím výzkumu rozdílu vlivu humorné vs. nehumorné inkongruence Carlson $(2011)^{33}$ zjistil významné korelace míry vnímané humornosti a míry zapamatování (s korelačními koeficienty $0,55 \mathrm{u}$ fotografií, 0,41 u názvů a 0,74 u frází).

$\mathrm{V}$ rámci této kategorie je třeba připomenout studie Zillmanna et al. (1984) a trojice Weaver, Zillmann a Bryant (1988), které zjistily, že děti hodnotily ironii a nadsázku jako humornější než formálně žertovný jazyk. Tyto techniky humoru na učení působily rušivým vlivem. Připomenout lze i studii autorů Ruleová a Auge (2005), kteří míru vnímané humornosti začlenili mezi objekty analýzy humorných prríkladů a jako jedno z kritérií zdokonalování humorných př́kladů žáky. A také studii dvojice Bingham a Hernandez (2009), v jejichž kurzu analýza míry vnímané humornosti sloužila jako jeden z prostředků rozvinutí diskuse o teorii sociálního jevu, s níž si komik zahrává.

Kategorie není jen banální definiční a metodologickou podmínkou. Může být i dimenzí míry a předmětem výuky $\mathrm{k}$ analýze i zdokonalování humorného zahrávání si s vyučovanou látkou. Podobně jako u kategorie vztažnosti se může komplikovat použitými technikami humoru. Volně odkazuje ke kategoriím individuálních charakteristik studenta a charakteru učiva.

\section{Individuální charakteristiky studenta}

Z trojice přehledových studií kategorii vyčleňuje pouze Šed’ová (2012), když odkazuje na studii trojice Matarazzoová, Duriková a Delaneyová (2010) ${ }^{34}$ a uvádí jejich zjištění: Humor zvýšil situační zájem jen u jedinců s nízkým individuálním zájmem o předmět, u jedinců s vysokým individuálním zájmem situační zájem snížil. Studie působí metodologicky záhadně. Implicitně sugeruje, že výsledná absence statisticky významného vlivu humoru na výkon $\mathrm{v}$ závěrečném testu by mohla být výsledkem rušivého vlivu na situační

\footnotetext{
33 VŠ studenti četli jednu ze dvou ekvivalentních variant série PowerPointových prezentací 18 fotografí s názvem a komentující frází (vždy smíšené ze slajdů obsahujících řešení inkongruence s humorem a bez humoru - motivační/inspirující). Např́iklad fotografie duhy nad jezerem a horami pojmenovaná Sny a komentovaná: „Sny jsou jako duhy, honí se za nimi jen idioti“ nebo „Sny jsou jako duhy, vedou k pokladům“. Zhruba polovina osob hodnotila míru humornosti, polovina míru inspirativnosti. Následoval dotazník na osobnostní vlastnosti a zvyky sledování televize. Následně test paměti s žádostí o popis všech fotografií (3-7 slovy), uvedení názvů a komentujících frází.

${ }^{34}$ Popíšeme jen podstatné z komplikovaného designu. VŠ studenti absolvovali jednu z variant (s humorem, bez humoru) počítačového vzdělávacího programu na násobení dvouciferných čísel bez použití kalkulačky či tužky a papíru. Program sestával z úvodního oznámení edukačního cíle, pretestu 30 př́kladů násobení dvojciferných čísel libovolnou technikou bez použití kalkulačky, výkladu techniky násobení v duchu, dvou slovních úloh k procvičení a závěrečného testu s 30 př́klady. Humor byl zaveden žertovnou podobou do úvodu a do situací ve slovních úlohách $-s$ vyučovanou technikou výpočtu si nezahrával, nevyžadoval znalost matematických pojmů. Individuální zájem o předmět a situační zájem byly měřeny dotazníky. Výsledky v testu byly závislé na výchozí schopnosti násobení a individuálním zájmu. Závislost na humoru nezjistili.
} 
zájem u jedinců $s$ vysokým individuálním zájmem o předmět. Což je úvaha, kterou najdeme již ve studii Zillmanna et al. (1980). Vztah mezi situačním zájmem před závěrečným testem a výkonem $\mathrm{v}$ závěrečném testu autoři neprozkoumali.

Co se týče pohlaví, z výzkumů nevyplývají žádné rozdíly. Věkem aktéři studií patří mezi předškoláky až vysokoškoláky. Charakteristika se nejeví jako okolnost, která by mohla bránit pozitivnímu vlivu humoru na učení. Otázkou je spíše přiměřenost, zvláště pochopitelnost humoru podle věku studentů - což výzkumy zohledňovaly jako metodologickou podmínku.

Výzkumně ověrovali souvislost s osobnostními vlastnostmi žáků Daviesová a Apter (1980). ${ }^{35}$ Ačkoli u použitých dotazníků vztah s vlivem humoru nezaznamenali, tuto oblast zkoumání otevřeli.

\section{Charakter učiva}

Z trojice přehledových studií ani jedna tuto kategorii nevyčleňuje. Učivo, které výzkumníci využívali úspěšně, variovalo od uměle vytvořených vět přes pohádky a príběhy, lekce $\mathrm{k}$ tématům $\mathrm{z}$ různých předmětů až po látku semestrálního kurzu. Z hlediska předmětů se jednalo o učivo od psychologie a sociologie přes statistiku po geologii. Přesto je vhodné kategorii vyčlenit. Objevily se totiž výzkumy, které ji tematizovaly a dospěly ke statisticky významným zjištěním.

Rozdíly v tématech učiva zaznamenali Daviesová a Apter (1980): vliv humoru byl nižší při učení prírodovědných předmětů a všeobecného přehledu než u jazyků, zeměpisu a dějepisu. Bryant et al. (1981) pracovali se dvěma variantami obtížnosti textu: snadná a těžká. Zjistili, že humor má větší efekt u jednoduššího obsahu. Obdobně jako u individuálních vlastností studentů je problematika teprve otevřená.

\section{Médium výuky}

Martin (2007) uvádí, že vliv nebyl zjištěn při zavedení humoru do výuky prostřednictvím textu učebnice. Banas et al. (2011) vyčleňují různá média výuky a vnímají je jako problematická při srovnávání výsledků studií. V souvislosti $s$ výzkumy, které nezjistily vliv humoru, zmiňují použití audionahrávky. Šed'ová (2012) kategorii nevyčleňuje.

Dalo by se uvažovat, že důvodem nezjištění vlivu u některých studií bylo využití jednokanálového média, rušivé působení virtuální výuky či absence bezprostřední práce učitele $s$ žáky a studenty. Připomeňme: Gruner (1967, 1970) - zvukové záznamy; Bolkan et al.

\footnotetext{
35 Děti ve věku 8-11 let nejdříve vyplnily pretest a osobnostní dotazníky (Torrance Test of Creativity, Porter and Cattel Children's Personality Questionnaire, The Junior Eysenck Personality Inventory). Následně sledovaly jednu z verzí (s humorem, bez humoru) série audiovizuálních edukačních prezentací poznatků z přírodovědných předmětů, všeobecného přehledu, cizího jazyka, zeměpisu a dějepisu (dětem neznámých, takže v pretestu získávaly maximálně 1 z 25 bodů). Humor via kreslené vtipy volně vztažené $\mathrm{k}$ tématům. Následoval posttest.
} 
(2018) a Bryant et al. (1981) - čtení textů; Matarazzoová et al. (2010) a Houserová et al. (2007) - počítačový program. $\mathrm{Na}$ druhé straně i př́i jednokanálové výuce byl prokázán vliv. Ve většině studií neměla výuka prováděná výzkumníky-učiteli či učiteli-výzkumníky povahu přirozeného experimentu ( $\mathrm{v}$ dimenzi od zcela prrirozeného $\mathrm{k}$ laboratorním) či akčního výzkumu, při kterém by docházelo $\mathrm{k}$ bezprostřednímu kontaktu učitele $s$ žáky či studenty. Tak tomu bylo pouze ve studiích Ruleová a Auge (2005), Bingham a Hernandez (2009) a Ziva (1988) - v gradaci „přirozenosti“. Smysluplnější než uvažovat o výzkumech, které by např. srovnávaly účinnost humoru ve výuce psaným textem $s$ nahrávkou, se jeví uvažovat o problematice přirozeného a komplexního média výuky - běžná interakce učitele $s$ žáky a studenty. Podstatná je pak kategorie tréninku učitele.

\section{Trénink učitele}

Martin (2007) uvádí, že nedostatečný vliv humoru by mohl vyplývat z toho, že učitelé nebyli trénováni v jeho efektivním použití. Banas et al. (2011) uvažují $\mathrm{o}$ nedostatku tréninku učitelů $\mathrm{v}$ efektivním použití humoru, které by mohlo vést $\mathrm{k}$ absenci používání sekvence: výuka pojmu - jeho ilustrace vtipem - parafráze pojmu. Šed'ová (2012) kategorii nevyčleňuje.

Př́ípravu a trénink vyžadovaly studie autorů Ruleová a Auge (2005) a Bingham a Hernandez (2009). Pouze Ziv (1988) školil učitele ve speciálním semi- náři „Humor in Teaching“, kde je učil vymýšlet a užívat vtipy prŕmo nasazené na učivo.

Výše uvedený přehled výsledků výzkumu vlivu humoru na výsledky učení žáků a studentů naznačuje, co vše by se mohlo stát předmětem systematické přípravy učitele. Pro daný výzkum by mohly být relevantní odborné studie z oblasti výuky humoru, dovednosti jej tvořit a využívat. Nejen v úvodu texty nabízejí výzvy a inspirace $\mathrm{k}$ používání humoru ve výuce, vhodná je rovněž studie Powella a Andersena (1985) - pointovaná k rozvoji schopnosti využívání humoru ve výuce u vysokoškolských učitelů.

Ziv (1988) upozorňoval, že nelze všechny učitele do užívání humoru tlačit. Což asociuje problematiku osobnostní disponovanosti učitelů. Např́klad Scott (1976) upozorňoval na dva typy osobností: jedni mají pouze schopnost si humor užívat a druzí jsou schopni jej i používat a vytvářet. Ti první by zřejmě byli hlavními klienty zvažované výuky; na rozdíl od těch kompletně bez smyslu pro humor. Ti druzí by naopak mohli být cenným zdrojem inspirace pro zvažovanou výuku.

\section{DiskUSE}

Po shrnutí výsledků práce lze konstatovat, že jsme vyhledali okolnosti, které mohou bránit pozitivnímu vlivu humoru na učení či $\mathrm{k}$ němu př̀spívat. $\mathrm{K}$ jejich tř́idění jsme využili osm kategorií převzatých z přehledových studií Martina (2007), Banase et al. (2011) a Šedové 
(2012) a vytvořili jednu novou - charakter učiva. Probrali jsme všechny kategorie z předchozích přehledových studií (Martin vyčleňoval šest; Banas et al. pět shodných s Martinem a jednu novou; Šed'ová dvě shodné s Martinem, z nichž jedna je shodná s Martinem i Banasem et al., a jedna nová). Konkretizovali jsme výklad významu a smyslu jednotlivých kategorií a naznačili jejich vzájemný vztah. U všech analyzovaných výzkumných studií jsme alespoň telegraficky přiblížili empirii, v níž jsou zakotvená výzkumná zjištění.

$\mathrm{Na}$ základě rozboru výzkumných studií lze konstatovat, stejně jako předchozí přehledové studie, že výsledky experimentálních výzkumů (využívajících testů výsledků výuky) působí rozporuplně. Avšak jen z hlediska abstraktního zájmu o to, zda zjistily statisticky významný pozitivní vliv. $Z$ hlediska zájmu o okolnosti, které mohou pozitivnímu vlivu bránit či $\mathrm{k}$ němu přispívat, dávají smysl i výsledky studií, které vliv nezjistily, či zjistily vliv negativní. Také jsme identifikovali metodologické kroky, které tato zjištění vysvětlují. $\mathrm{V}$ případě studií Grunera $(1967,1970)$ a Houserové et al. (2007) autoři do výzkumu nezavedli citlivost vůči efektu „na úkor“. Bryant et al. (1981) na rozdíl od Kaplana a Pascoea (1977) netestovali po 6 týdnech. Matarazzoová et al. (2010) neprozkoumali vztah mezi situačním zájmem před závěrečným testem a výkonem $\mathrm{v}$ závěrečném testu. Negativní vliv zjištěný ve studiích Kaplana a Pascoea (1977) a Schmidta (1994) vyplývá z efektu „na úkor“; ve studiích
Zillmanna et al. (1984), Weavera et al. (1988) a trojice Bolkana et al. (2018) vyplývá z použitých technik humoru (nadsázka a ironie).

Rovněž můžeme konstatovat, že kategorie trvání výuky a médium výuky se vzhledem ke zbývajícím jeví jako irelevantní. Výzkum problematiky individuálních charakteristik studenta a charakteru učiva byl zatím pouze nastíněn. Kategorii vnímání humornosti studentem lze $\mathrm{v}$ rámci dimenze míry považovat za doplňující pro výzkum ostatních kategorií či jako možný objekt analýzy př́i výuce. Kategorie vztažnosti humoru $\mathrm{k}$ látce, dávkování humoru a techniky humoru jsou těmi, které mohou nabídnout poznatky pro praxi. Největší dluh je ve výzkumu technik humoru. Problematika tréninku učitele se jeví jako hlavní výzva pro výzkum v budoucnosti.

Limitem této studie je skutečnost, že jsme neřešili původ autorů. Vzhledem ke zvoleným vyhledávačům a databázím a použití českých a anglických klíčových slov prezentuje analyzovaný soubor studií pouze výzkumy z anglosaského světa (pokud $\mathrm{k}$ němu započítáme i Izrael). Omezením studie je nepodniknutí činností, jimiž bychom se dobrali $\mathrm{k}$ pramenům, které nejsou monitorované anglosaskými databázemi a ve kterých by mohly být $\mathrm{k}$ nalezení další studie námi určeného zaměření.

Dále si uvědomujeme, že cíle výuky mohou být i jiné než testovatelná míra osvojení učiva. Nezkoumali jsme 
výzkumy vlivu na kreativní myšlení, i když bylo testované. Nevyhledávali jsme problematiku vlivu humoru při výuce, jejímž hlavním cílem je poskytnout netestovatelný zážitek. A podstatný limit vyplývá ze soustředění na výzkumy experimentální, zaměřené na praktické využití připraveného humoru. Mimo zůstává celá oblast spontánního situačního humoru.

Soustředíme se pouze na přehled výsledků výzkumů (vs. metodologických prístupů, teorií či praktických aplikací). Zvláštní pozornost by zasloužil rozbor teorií psychologických mechanismů zprostředkujících zkoumaný vliv, obdobně jako propracovanost používané experimentální metodologie. Vzhledem $\mathrm{k}$ omezenému množství studií se v této oblasti výzkumu zatím nediskutují sofistikovanější metodologické otázky, jako např. struktura používaných testů, jejich psychometrické charakteristiky či práce se sekvencí „pretest - posttest - retenční test“. (Většina studií se spokojila se základním experimentálním designem.)

\section{ZÁVĚR}

Banas et al. (2011) v nadpisu své přehledové studie píši o 40 letech výzkumu humoru $\mathrm{v}$ edukačním prostředí. Dnes uvažujeme o 50 letech. Množství výzkumů vlivu humoru na výsledky učení žáků a studentů lze označit za skromné. Za hlavní přínos lze považovat pochopení, proč do 70 . let většina studií nebyla schopna zjistit statisticky významný vliv.
Možná ještě významnější jsou inspirace, které výzkumná zjištění nabízejí praxi byt bez záruky, vzhledem ke skromnému množství výzkumů, $z$ toho jen několika provedených $\mathrm{v}$ praxi běžné výuky.

Pro využití poznatků o okolnostech, které brání pozitivnímu vlivu humoru či jej posilují, je výchozí rozlišení jeho využití k vyvolání bdělosti, tzv. situačnímu zájmu, nebo k mobilizaci psychofyziologických mechanismů paměti (jejího posílení prožitou emocí) či vyšších úrovní myšlení. Pokud jde o první záměr, je třeba humor použít předem, $v$ míře nekonkurující výkladu látky, včas, jasně oddělit od výkladu a obsahem s látkou nesouvisejícím. Pokud se jedná o druhý záměr, je podstatná obsahová vztažnost k látce, načasování v sekvenci „výuka pojmu - jeho ilustrace vtipem - parafráze pojmu“. Dále je důležité vědomí toho, že vliv na pamět bude fungovat na úkor paměti pro látku prezentovanou bez humoru a že je třeba vyhnout se technikám absurdní nadsázky a ironie. Rovněž důležité je, aby učitel nebyl vnímán jako klaun (tzn. vyhnout se mechanické frekvenci a použít maximálně čtyři humorné prýiklady za lekci). Pokud je záměrem zvláště mobilizace vyšších úrovní myšlení, lze doporučit spojení výuky analýzy nebo i tvorby humoru s výukou látky. Zvláště žádoucí by byl trénink učitelů.

Co se týče budoucnosti výzkumu, nejde pouze o množství umožňující metaanalýzy, replikace dodávající věrohodnosti, doplňování mezer a rozvoj odkrytých témat. Soudíme, že lze uvažovat o jedné tematické a jedné metodologické prioritě. 
Za obsahovou prioritu bychom označili výzkum technik humoru. Za zvláště naléhavé považujeme, že výzkumně neprobádaná zůstává otázka alternativ $\mathrm{k}$ technikám, které jsou založené na zkreslení povahy absurdní nadsázkou či zlehčení ironickou kontradikcí, a mohou působit negativně. $\mathrm{Za}$ metodologickou prioritu bychom označili realizaci akčního výzku$\mathrm{mu}$, při kterém by docházelo $\mathrm{k}$ prrirozenému bezprostřednímu kontaktu učitele s žáky či studenty. Jako hlavní výzva pro výzkum ve vzdálenější budoucnosti se jeví problematika tréninku učitele - závislá na tom, zda se tento jev bude rozvíjet.

\section{Literatura}

Banas, J. A., Dunbar, N., Rodriguez, D., \& Liu, S. J. (2011). A review of humor in educational settings: Four decades of research. Communication Education, 60(1), 115-144.

Bingham, S. C., \& Hernandez, A. A. (2009). "Laughing matters": The comedian as social observer, teacher, and conduit of the sociological perspective. Teaching Sociology, 37(4), 335-352.

Bolkan, S., Griffin, D. J., \& Goodboy, A. K. (2018). Humor in the classroom: the effects of integrated humor on student learning. Communication Education, 67(2), 144-164.

Bryant, J., Brown, D., Silberberg, A. R., \& Elliott, S. M. (1981). Effects of humorous illustrations in college textbooks. Human Communication Research, 8(1), 43-57.

Carlson, K. A. (2011). The input of humor on memory: Is the humor effect about humor? Humor, 24 (1), 21-41.

Davies, A. P., \& Apter, M. J. (1980). Humour and its effect on learning in children. In P. E. McGhee \& A. J. Chapman (Eds.), Children's humour (s. 237-253). Chichester: John Wiley \& Sons.

Derks, P., Gardner, J. B., \& Agarwal, R. (1998). Recall of innocent and tendentious humorous material. Humor, 11(1), 5-19.

Gilliam, L. M. (2019). Magical management in the classroom: Using humor to speak their language. London: Rowman \& Littlefield.

Gorham, J. (1988). The relationship between verbal teacher immediacy behaviors and student learning. Communication Education, 37(1), 40-53.

Gorham, J., \& Christophel, D. M. (1990). The relationship of teachers' use of humor in the classroom to the immediacy and student learning. Communication Education, 39(1), 46-62.

Gruner, C. R. (1967). Effect of humor on speaker ethos and audience information gain. Journal of Communication, 17(3), 228-233.

Gruner, C. R. (1970). The effect of humor in dull and interesting informative speeches. Central States Speech Journal, 21(3),160-166.

Gruner, C. R. (1976). Wit and humor in mass communication. In A. J. Chapman \& H. C. Foot (Eds.), Humor and laughter: Theory, research, and applications (s. 287-311). London: John Wiley \& Sons. 
Hauck, W. E., \& Thomas, J. W. (1972). The relationship of humor to intelligence, creativity, and intentional and incidental learning. Journal of Experimental Education, 40(4), 52-55.

Hays, E. R. (1970). Ego-threatening classroom communication: A factor analysis of student perceptions. Speech Teacher, 19(1), 43-48.

Houser, M. L., Cowan, R. L., \& West, D. A. (2007). Investigating a new education frontier: Instructor communication behavior in CD-ROM texts - do traditionally positive behaviors translate into this new environment? Communication Quarterly, 55(1), 19-38.

Kaplan, R. M., \& Pascoe, G. C. (1977). Humorous lectures and humorous examples: Some effects upon comprehension and retention. Journal of Educational Psychology, 69(1), 61-65.

Kelley, D. H., \& Gorham, J. (1988). Effects of immediacy on recall of information. Communication Education, 37(3), 198-207.

Klein, D. M., Bryant, J., \& Zillmann, D. (1982). Relationship between humor in introductory textbooks and students' evaluations of the texts' appeal and effectiveness. Psychological Reports, 50(1), 235-241.

Mareš, J. (2013). Přehledové studie: jejich typologie, funkce a způsob vytváření. Pedagogická orientace, 23(4), 427-454.

Martin, R. A. (2007). The psychology of humor: An integrative approach. Burlington, MA: Elsevier Academic Press.

Matarazzo, K. L., Durik, A. M., \& Delaney, M. L. (2010). The effect of humorous instructional materials on interest in a math task. Motivation \& Emotion, 34(3), 293-305.

Oppliger, P. A. (2003). Humor and learning. In J. Bryant, D. Roskos-Ewoldsen \& J. R. Cantor (Eds.), Communication and emotion: Essays in honor of Dolf Zillmann (s. 255-273). Mahwah: Lawrence Erlbaum Associates.

Powell, J., \& Andersen, L. W. (1985). Humor and teaching in higher education. Studies in Higher Education, 10(1), 79-90.

Rule, A. C. \& Auge, J. (2005). Using humorous cartoons to teach mineral and rock concepts in sixth grade science class. Journal of Geoscience Education, 53(5), 548-558.

Sanders, J. A., \& Wiseman, R. L. (1990). The effects of verbal and nonverbal teacher immediacy on perceived cognitive, affective, and behavioral learning in the multicultural classroom. Communication Education, 39(4), 341-353.

Scott, T. M. (1976). Humor in Teaching. Journal of Physical Education and Recreation, 47(8), 18.

Shade, R. A. (1996). License to laugh: Humor in the classroom. Englewood, Colo.: Teacher Ideas Press.

Schmidt, S. R. (1994). Effects of humor on sentence memory. Journal of Experimental Psychology: Learning, Memory, \& Cognition, 20(4), 953-967. 
Schmidt, S. R. (2002). The humour effect: Differential processing and privileged retrieval. Memory, 10(2), 127-138.

Schmidt, S. R., \& Williams, A. R. (2001). Memory for humorous cartoons. Memory \& Cognition, 29(2), 305-311.

Šed’ová, K. (2012). Pedagogické efekty humoru ve výukové komunikaci. Pedagogika, $62(4), 426-441$.

Šed’ová, K. (2013). Humor ve škole. Brno: Masarykova univerzita.

Teslow, J. L. (1995). Humor me: A call for research. Educational Technology Research \& Development, 43(3), 6-28.

Torok, S. E., McMorris, R. F., \& Lin, W. (2004). Is humor an appreciated teaching tool? Perceptions of professors' teaching styles and use of humor. College Teaching, 52(1), $14-20$.

Vance, C. M. (1987). A comparative study on the use of humor in the design of instruction. Instructional Science, 16, 79-100.

Wakshlag, J. J., Day, K. D., \& Zillmann, D. (1981). Selective exposure to educational television programs as a function of differently paced humorous inserts. Journal of Educational Psychology, 73(1), 27-32.

Wanzer, M. B., \& Frymier, A. B. (1999). The relationship between student perceptions of instructor humor and students' reports of learning. Communication Education, 48(1), 48-62.

Wanzer, M. B., Frymier, A. B., \& Irwin, J. (2010). An explanation of the relationship between instruction humor and student learning: Instructional humor processing theory. Communication Education, 59(1), 1-18.

Weaver, J., Zillmann, D., \& Bryant, J. (1988). Effects of humorous distortions on children's learning from educational television: Further evidence. Communication Education, 57(3), 181-187.

Zillmann, D., Williams, B. R., Bryant, J., Boynton, K. R., \& Wolf, M. A. (1980). Acquisition of information from educational television programs as a function of differently paced humorous inserts. Journal of Educational Psychology, 72(2), 170-180.

Zillmann, D., Masland, J. L., Weaver, J. B., Lacey, L. A., Jacobs, N. E., Dow, J. H., Klein, C. A., \& Banker, S. R. (1984). Effects of humorous distortions on children's learning from educational television. Journal of Educational Psychology, 76(5), 802-812.

Ziv, A. (1976). Facilitating effects of humor on creativity. Journal of Educational Psycho$\log y, 68(3), 318-322$.

Ziv, A. (1988). Teaching and learning with humor: Experiment and replication. Journal of Experimental Education, 57(1), 5-15. 
Mgr. et Mgr. Michaela Kubátová,

Univerzita Karlova, Pedagogická fakulta, katedra psychologie;

e-mail: michaela.pejchalova@pedf.cuni.cz

PhDr. Miroslav Klusák, CSc.,

Univerzita Karlova, Pedagogická fakulta, katedra psychologie;

e-mail:miroslav.klusak@pedf.cuni.cz

\section{KUBÁTOVÁ, M., KLUSÁK, M. Revision of Analyses of Research on the Effect of Humour Used by Teachers on the Results of Pupils' and Students' Learning}

The review study continues the work of three relevant reviews of research on humour in the educational setting. The focus is only on research which studied the effect of teachers' humour on the results of learning, and "results of learning" were operationalised by tests of acquired knowledge. The question is what circumstances influence the effect of humour. The analysis of 20 research studies rendered nine categories of circumstances problematising the effect of humour: the duration of instruction; the relatedness of humour to the subject matter; the dosage of humour; humour techniques; students' perception of humorousness; students' individual characteristics; the character of the subject matter; the medium of instruction, and the training of teachers. According to the research that was analysed, a positive effect is supported by: longer duration of the instruction; the relatedness of humour to substantial information; an appropriate and even dosage of humour; inserting humour after explaining new knowledge and repeating it after illustration with humorous examples; active work with humour during lessons; training of teachers in using humour, and students' perception of humour as humorous. The problems of students' individual characteristics, the character of the subject matter, and especially techniques of humorous punchline construction call for further research.

Keywords: teacher's humour, influence of humour on learning, relatedness of humour, humour techniques 